Portland State University

PDXScholar

\title{
The Lasting Effects of U.S. Intervention in Guatemala
}

Katherine A. Gaffey

Portland State University

Follow this and additional works at: https://pdxscholar.library.pdx.edu/honorstheses

Part of the International Relations Commons Let us know how access to this document benefits you.

\section{Recommended Citation}

Gaffey, Katherine A., "The Lasting Effects of U.S. Intervention in Guatemala" (2020). University Honors Theses. Paper 842.

https://doi.org/10.15760/honors.861

This Thesis is brought to you for free and open access. It has been accepted for inclusion in University Honors Theses by an authorized administrator of PDXScholar. Please contact us if we can make this document more accessible: pdxscholar@pdx.edu. 
The Lasting Effects of U.S. Intervention in Guatemala

\author{
By \\ Katherine A. Gaffey
}

An undergraduate honors thesis submitted in partial fulfillment of the

requirements for the degree of
Bachelor of Arts
in
University Honors
And
International Studies

And

Political Science

Thesis Adviser

Joshua Eastin

Portland State University 


\section{Table of Contents}

Introduction............................................................

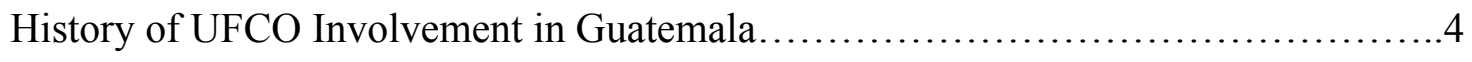

The 1954 Coup-Operation Success......................................... 8

Brief History of the 36 year long Civil War................................... 10

U.S. Involvement Pre and During the Guatemalan Civil War........................13

Gender-based Violence pre and during Civil War.................................19

Conditions Open for Drug Trafficking .....................................22

Human Trafficking in Guatemala............................................26

Immigration Today- An Implication of the War................................ 33

Alternative Explanations.................................................. 38

Limitations........................................................41

Conclusion..........................................................41

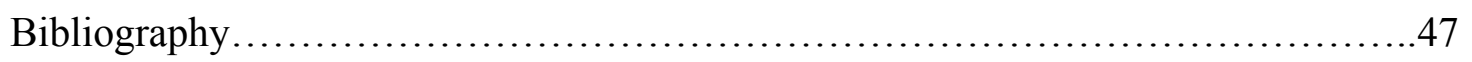




\section{Introduction}

Guatemala has been sucked into a cycle of civil unrest, poverty and mass migration. How did this happen? In order to understand the issues Guatemalans face today, a historical analysis of Guatemala's relationship with the U.S. is needed. Guatemala has had a long and tumultuous history of U.S. intervention within its borders. This essay will examine the role of the 1954 CIA coup and the United Fruit Company in fostering the Guatemalan Civil War and the implications of that war for ongoing crime and instability in the country today. Some of the most pressing issues Guatemalans face today are high migration rates, femicide, and human trafficking. Guatemalan migration is on the rise; from October 1st, 2017 to August 31st, the U.S. government arrested 42,757 Guatemalans who attempted to immigrate to the U.S. with their families. This is the highest number of migrant families from a single country that U.S immigration has seen. (Yates-Doerr, 2018). According to the U.S. Department of State's 2019 Trafficking in Persons Report, Guatemala is currently a Tier 2 country for human trafficking. Guatemala does not meet the standards for eliminating trafficking, but is making an effort. According to UNICEF, there are nearly 48,500 victims of sex trafficking in Guatemala, creating illegal profits equivalent to $2.7 \%$ of the Gross Domestic Product (Velásquez Gómez \& Skoog, 2016). Why is this?

In 1954, a CIA supported military coup was launched against democratically elected Colonel Jacobo Arbenz bringing rise to the 36 year Civil War from 1960-1996 in which over 200,000 lives were taken and over 45,000 missing (Ewing, 2018). The Civil War ended with the 1996 Guatemala Peace Treaties and a hope for a better future for the country, but unfortunately that was not the case. Instead, there was a surge in criminal violence and a weakening of 
democratic institutions, leading to a situation in which Guatemala was unable to respond to the multiple threats attacking its democracy. Human trafficking was able to flourish and migration to the U.S. rose tremendously. In this paper, I trace the implications of U.S. intervention in Guatemala and the effects it had on their security and stability, taking trafficking, current day femicide and a rise in immigration as an example of the types of unintended consequences that can emerge when foreign intervention creates civil unrest. In this essay, I argue that the role of U.S. intervention through the United Fruit Company's vast involvement in Guatemala and the CIA backed 1954 coup are key causal factors for the Guatemalan Civil War, which has now led to an environment conducive for the normalization of gender based violence and human trafficking. This in turn, has resulted in high rates of Guatemalans migrating to the U.S. border where they are being met with racist anti-immigrant rhetoric. In order to understand why so many Guatemalans are fleeing their country, an analysis of their history and the role the U.S. played in it is essential. The US role in the 1954 coup placed Guatemala on a trajectory of civil conflict that the country is still affected by today.

\section{History of UFCO Involvement in Guatemala}

According to Dosal (1993), for forty years the United Fruit Company (UFCO) controlled Guatemala's railroads, wharves, shipping and telegraphs. The government also delegated control of their two leading exports, coffee and bananas, to UFCO. The U.S. government was very involved in this process. The U.S. urged the Guatemalan government to adopt policies American enterprises would find favorable and helped UFCO during their contractual negotiations (Dosal, 1993). This occurred despite skepticism from the Departments of State and Justice regarding UFCO's monopoly power. UFCO became known as "el pulpo" octopus in Spanish, due to its 
extensive control of more than just their banana plantations (Dosal, 1993). Schlesinger and Kinzer argue that UFCO was essentially a state within a state due to its ownership of Guatemala's telephone and telegraph facilities, its administration of its Atlantic harbor and monopolization of its banana export. Also, UFCO's subsidiary company, International Railways of Central America (IRCA) owned 887 miles of railroad tracks in Guatemala, which equated to nearly the whole entire country (Schlesinger and Kinzer, 2005, p.12).

UFCO workers did enjoy better working conditions than most farm laborers in Guatemala; they were provided with adequate housing, medical facilities and a school for employees' children. But, many of the American overseers of the company were blatantly racist. UFCO policy required "all persons of color to give right of way to whites and remove their hats while talking to them" (Schlesinger and Kinzer, 2005 p.71). Also, UFCO did not allow for any organized labor unions among its employees. During the years of the Ubico dictatorship, peasants that were performing forced labor for plantation owners were at least given their own small plots of land, but UFCO rejected this idea. Cole Blasier, an American historian, argues that for many Guatemalans, UFCO represented the United States. UFCO was responsible for bribing politicians, pressuring governments and intimidating opponents. For Guatemalans, they felt as if their country was "being mercilessly exploited by foreign interests which took huge profits without making any significant contributions to the nation's welfare" (Schlesinger and Kinzer, 2005, p. 73).

UFCO was very well connected to the Eisenhower administration. The Secretary of State, John Foster Dulles had his New York law firm, Sullivan and Cromwell representing UFCO. Allen Dulles, the director of the Central Intelligence Agency (CIA) served on UFCO's board of 
trustees and owned shares of the company (Bryjak, 2017). Ed Whitman was the company's top public relations officer and husband of Ann Whitman, Eisenhower's private secretary. Whitman made a film, Why the Kremlin Hates Bananas, presenting UFCO as being on the front lines of the fight against communism (Koeppel, 2008). UFCO then began to pay for journalists to travel to Guatemala to learn their side of the story. The U.S. press began to print stories about mass arrests and tortures committed by the Arbenz regime. On the 15th of June, John Foster Dulles declared that "Guatemalans were living under a Communist type reign of terror" which was untrue (Schlesinger and Kinzer, 2005, p. 11). One of the main issues fueling these false accounts of the situation in Guatemala were the land reforms enforced by democratically elected Guatemalan president, Jacobo Arbenz.

Before Arbenz was elected, UFCO essentially was playing puppet master with 1931-1944 Guatemalan dictator Jorge Ubico, guiding him into allowing them to own or lease three million acres of land and operate fifteen hundred miles of railroad. UFCO worked very closely with the Ubico dictatorship and exploited the Guatemalan people. Ubico passed harsh vagrancy laws which forced indigenous people who did not own land to work for local landowners 100 days a year. Ubico also made it legal for landowners to "murder stubborn or rebellious Indians" (Bucheli, 2008). Ubico was considered to be a very strong ally to the U.S. and especially UFCO. He was taken down by a pro-democracy uprising amongst striking schoolteachers and was replaced in 1945 by Juan Jose Arevalo, an exiled college professor keen on social reform. He only imposed a small amount of regulatory measures against UFCO, yet the army still attempted almost thirty coups during his six years in office due to his "reformist" agenda (Fisher, 2012). Jacobo Arbenz was then democratically elected in 1951. 
From the very beginning Arbenz made clear that once elected he would prioritize building a highway to the Atlantic to "end the IRCA/United Fruit stranglehold on the nation's foreign trade" (Schlesinger and Kinzer, 2005, p.74). He also planned on building a new electric power plant in order to end reliance on the American owned facility given that it was the only major generating outlet within the country. Arbenz was an advocate of agrarian reform and believed that unequal land distribution was one of the leading causes hindering economic development (Dosal, 1993). His program expropriated 209,842 acres of uncultivated land, mainly belonging to UFCO, to poor laborers. UFCO wanted nearly $\$ 16$ million for the land, but Guatemala offered UFCO's declared valuation for tax purposes of $\$ 627,572$. UFCO undervalued the property in order to reduce its tax liability (Schlesinger and Kinzer, 2005). Clearly, this was infuriating for UFCO who controlled nearly 40,000 jobs in Guatemala and had investments in the country valued at $\$ 60$ million. On April 20, 1954, a complaint was delivered to Guatemalan authorities by the U.S. State Department demanding just evaluation for the land equating to nearly $\$ 16$ million. They based their claim on international law that requires fair compensation for land that is seized by foreigners, despite domestic law (Schlesinger and Kinzer, 2005). In response, Arbenz continued his plans for agrarian reform and expropriated more uncultivated UFCO land bringing the total to 386,901 acres. They offered $\$ 500,000$ for the newest land they had redistributed (Schlesinger and Kinzer, 2005). During this time negotiations between Guatemalan officials and the State Department were occuring, but Arbenz already sensed what was going to occur. In his annual message to Congress in March 1954 he stated:

The essential character of the international situation with relation to Guatemala is that, as a consequence of the agrarian reform and the economic and social development of the 
country, we face a growing threat of foregin intervention in the internal affairs of

Guatemala, placing in danger the stability of our constitutional life and the integrity of our national independence (Schlesinger and Kinzer, 2005, p.77).

At that moment, UFCO was indeed planning a way in which to convince the American government that Arbenz was a communist and a threat to freedom. They hired influential lobbyists and publicists in order to create a climate in the U.S. that feared Arbenz and favored his overthrow.

\section{The 1954 Coup- Operation Success}

According to unclassified CIA documents, elites in Guatemala persuaded U.S. journalists and members of Congress that the Guatemalan government was moving further toward Communism (Barrett, 2011). Many of those elites were a part of UFCO. Barret argues that the U.S. feared that Arbenz was a Communist threat and used the CIA to overthrow him in the 1954 coup also known as "Operation Success." After the coup, there was no serious evidence that could tie Guatemala to the Soviets (Schlesinger and Kinzer, 2005). What the majority of journalists latched onto to support the claim that Arbenz was a communist was his land reform plan. They warned that Communists would "use the program as a stepping stone to take over Guatemala" (Schlesinger and Kinzer, 2005, p.107). Also, multiple U.S. Congressmen argued the program was similar to the nationalization of oil companies in Iran, even though both of these programs were done legally under local law (Schlesinger and Kinzer, 2005).

A significant part of the overthrow of the Arbenz government was psychological warfare. Through multiple raids, small scale attacks and anti-Arbenz journalists, the U.S. worked to persuade Guatemala's citizens and political/military leaders that a large scale invasion was going 
to occur in order to unnerve Arbenz and others. Through this strategy, the government collapsed without much of a struggle (Barret, 2011). After the coup, Arbenz's reforms were nullified, bringing peace of mind back to UFCO and the U.S. With CIA assistance, President Castillo Armas came into power with his anti Communist, yet dictatorial government agenda. U.S. officials believed that if they could turn Guatemala into a "showcase for democracy" it would be the best defense against communism (Brockett, 2010). But, at the same time, the U.S. pretended they had nothing to do with the coup as cries for a return to democracy in Guatemala began under the Castillo Armas authoritarian regime. Despite this, the overthrow became known as one of the CIA's well-known successes and the U.S. continued its support of Castillo Armas. Brockett emphasizes that many of the leading scholars regarding the United States and Central America relationship argue that material and security interests were linked in the 1954 coup. The United States has always wanted to "control" or "dominate" the region (Brockett, 2010). The CIA took their success in Guatemala and used it as an example of what could be done in operations against Sukarno in Indonesia and Castro in Cuba (Schlesinger and Kinzer, 2005).

As a result of the coup, UFCO essentially disintegrated. The Justice Department had filed an antitrust suit threatening UFCOs operations in Guatemala. UFCO ended up having to surrender some of its trade to local companies and the majority of its land to local businessmen. It also had to give up ownership interest of IRCA. But, in 1972 they sold all remaining land holdings in Guatemala to the Del Monte corporation, which also has a dark history within Guatemala. 


\section{Brief History of the 36 year long Civil War}

In the years before the start of the war, the military gained tremendous political control, especially with the passing of the 1944 Constitution. The Constitution granted the military the responsibility of protecting democracy, and "gave it the ability to intervene in matters related to rights and freedoms" (Ewing, 2018). The army was able to use this constitutional mandate with support from the CIA during the 1954 coup. After the removal of Arbenz, many military leaders succeeded as president. They demolished the agrarian reforms and left the Guatemalan farmers with little to nothing to survive. Divisions began to form between military groups with a rise in assassinations and attempts to remove the president. Many former soldiers turned to support from banana workers and farmers who opposed the military government and supported Arbenz. A multitude of rebel groups began to form the leftist guerrilla front that fought the State. In 1960, a group of armed insurgents known as Unidad Revolucionaria Nacional Guatemalteca (URNG) started an unsuccessful uprising against the Guatemalan government, sparking the beginning of the civil war (COHA, 2011). For many years after, URNG continued to fight against the repression and human rights abuses committed by the various military dictators that ruled Guatemala. The army counteracted by exerting its power over every community in Guatemala through creating an intelligence program that included mobile military police, paramilitary death squads and sophisticated torture techniques (Ewing, 2018). Since the guerrillas were mainly located in rural communities, it was incredibly hard to tell the difference between civilians and guerrillas, leading to mass amounts of civilian deaths. As the military continued to infiltrate rural villages, the government became removed of civilians and was almost made up of entirely military members. 
According to declassified intelligence documents, during the 1960s, the U.S. was highly involved in the training and equipping of Guatemalan security forces that were responsible for the deaths of hundreds of thousands of people during the Civil War. Bracken argues that the worst period was when President Rios Montt, a man that was trained at the United States Army School of the Americas in the Panama Canal Zone, came to power through a coup, with the support of the CIA. His goal was to "drain the sea" of the guerrilla movement and eradicate civilian support (Bracken, 2016). During his term, Montt led what is known as "Scorched Earth" in which more than 70,000 people died and went missing. He specifically targeted indigenous Maya communities, attacking 626 villages and tried to exterminate the Ixil ethnic group, a Mayan Indian community. According to Farah, the CIA was aware of the mass killings of Indian villagers. He massacred children and the elderly, people who could not have been guerrillas, it was genocidal. Bracken points out that in 1977, Jimmy Carter tried to pressure Guatemala to stop the abuses by banning the sale of military weapons to Guatemala. Ronald Reagan became president and all the efforts of Carter were reversed. Bracken argues that Reagan befriended Montt believing he was committed to democracy and reform. He provided financial support and military advising, and lifted the U.S. embargo (Bracken, 2016). Reagan met with Rios Montt in Honduras in 1982, stating he was "a man of great integrity" and "totally dedicated to democracy" and that he knew Montt "wants to improve the quality of life for all Guatemalans and to promote justice" (Grandin, 2013 and Kinzer, 2018). He promised that his administration would do all they could to support his "progressive efforts" (Kinzer, 2018). Only 10 days before this meeting, a declassified U.S. document shows that the State Department was informed of a substantiated allegation of "a large-scale killing of Indian men, women and children in a remote area by the 
Guatemalan army" (Grandin, 2013). According to Grandin, there are other classified documents that expose that the White House was not concerned about the massacres as much as they were concerned about "countering the bad publicity" (Grandin, 2013). In a declassified Department of State document, State officials are discussing that if President Lucas "can go it alone in his policy of repression, there is no need for the U.S. to provide the GOG with redundant political and military support" because "The provisioning of such assistance would needlessly render us a complicit party in the repression" (Grandin, 2013). The U.S. knew exactly what was occurring in the Guatemalan civil war and instead of intervening to help avoid the genocide, the U.S. stood idly by. After Reagan's endorsement of Montt, Guatemalan soldiers went to the village of Dos Erres and slaughtered at least 162 people over three days (Grandin, 2013). With U.S. support, Montt continued attacking indigenous communities, creating instability and risk for Guatemalans. A declassified 1966 memo from a U.S. State Department security official showed that the U.S. even set up safe houses in the presidential palace to be used by Guatemalan security agents and U.S. contacts, "the safe house became headquarters for Guatemala's 'dirty way' against leftitst insurgency and suspected allies" (Farah, 1999). During the Cold War in the 1960s and 70s, the U.S. even gave the Guatemalan military $\$ 33$ million in aid, despite being aware of the terrible track record they held on human rights (Farah, 1999). According to a 1994 Defense Intelligence Agency report, in the 1980s as the U.S. continued to provide financial aid to Guatemalan military intelligence, they were dumping suspected guerrillas (dead and alive) out of airplanes into the ocean. This was a way for them to remove the evidence that prisoners had been tortured and killed (Farah, 1999). 


\section{U.S. Involvement Pre and During the Guatemalan Civil War}

According to Barret, during the late Cold War period, the 1954 overthrow came to be seen as shameful. It damaged American interests in Latin America and "strengthened deep-seated anti-Americanism throughout the continent" (Schlesinger and Kinzer, 2005, p.229). The governments following the overthrow of Arbenz were far more violent, repressive and damaging to Guatemala as a whole. With the help of the U.S. Castillo Armas took power after the coup. Despite the U.S. refusing to provide any aid to Guatemala during the Arévalo and Arbenz administrations, they provided the Armas administration with $\$ 80$ million in the first three years after the coup (Schlesinger and Kinzer, 2005). According to Schlesinger and Kinzer, these funds revitalized some areas of the private sector, but did close to nothing for the nation's poor. Armas wanted to return the country's economy to the old days of relying on the coffee and banana crop. He was able to drive "all but one half of one percent of the peasants who had won plots under the Arbenz agrarian reform off their new land" (Schlesinger and Kinzer, 2005, p.229). Even though many of these poor farmers were able to improve their lives exponentially due to the Arbenz land reforms, their newfound success was stripped away from them. Additionally, Armas was antiunion and focused on press censorship. In 1955, he postponed the following year's scheduled presidential election and instead only held congressional elections in which he solely permitted candidates of his own party, the National Liberation Movement to run (Schlesinger and Kinzer, 2005). According to Schlesinger and Kinzer, Castillo Armas had the "unswerving support of the American government” (p.233).

The Eisenhower administration had a Cold War focused agenda of making Guatemala an example of democracy. After visiting Guatemala, Vice-President Nixon claimed that this was the 
first instance in history that a free government was replacing a Communist one, and that the world was watching to see who could do a better job. Despite the aid provided by the U.S. the situation in Guatemala worsened. According to Schlesinger and Kinzer, many Guatemalan officials of this new regime "considered Castillo Armas' victory a license to steal money" (p.234). Distrust in the government resulted in plots against the administration occurring almost weekly. Eventually, Armas was assassinated, though no one knows who exactly did it. After the death of Armas, the U.S. provided \$97,00 in “campaign funds" to José Luis Cruz Salazar in order to keep Miguel Ydígoras Fuentes from becoming the next president (Schlesinger and Kinzer, 2005). Ydígoras at the time was the ambassador to Colombia. He won the election, but the official electoral tribunal announced Ortiz Passarelli as the winner. As a result, Ydígoras' followers flooded the streets in protest, newspapers "denounced the fraud" and Ydígoras himself threatened to stage a coup (Schlesinger and Kinzer, 2005). Following the election announcement, Ydígoras was called to a meeting at the National Palace in which the American Embassy guaranteed U.S. approval for a settlement. If Ydígoras won the next election, it would be recognized. Despite the U.S. funding his opponent, he eventually won the 1958 election and held office for six years. At first the people were supportive of Ydígoras, but then the U.S. approached him for a favor. In the eyes of the U.S. government, Ydígoras owed the U.S. a favor because of the National Palace meeting in which they ensured recognition of his presidential candidacy. The U.S. was planning an invasion of Cuba in order to overthrow Fidel Castro and needed Guatemala to provide them with a base of operations. Ydígoras agreed to cooperate with the U.S. in return for firm U.S. backing in Guatemala. The presence of the CIA in Guatemala training Cuban exiles to overthrow Castro became public knowledge and upset many Guatemalans. According to 
Schlesinger and Kinzer, for the many officers in Guatemala that were schooled with a strong nationalist framework, this situation was humiliating and infuriating. A growing divide began to form within Guatemala. On November 13th, 1960 half of the Guatemalan Army staged an uprising at Fort Matamoros in Guatemala and seized it (Schlesinger and Kinzer, 2005). An additional group took control of Puerto Barrios on the Atlantic and the barracks of Zacapa (Schlesinger and Kinzer, 2005). Due to the fear that a coup could occur in which the Bay of Pigs operation would be sidelined, the U.S. helped Ydígoras stop the revolt. They sent several CIA B-26 bombers which were piloted by Cuban exiles to attack the rebels. President Eisenhower sent five U.S. Navy vessels to patrol off Guatemala's coast (Schlesinger and Kinzer, 2005). Due to the strong military response from the U.S. the revolt was crushed. Guatemalans not working with the U.S. began to see the Guatemalan government as a "puppet for foreign interests" (Schlesinger and Kinzer, 2005, p.240). Rebel leaders began preaching that “"the only way to end the calamities torturing our country is to overthrow the despotic rule of Ydígoras and set up a government which proves by deeds that it is worthy of the people's trust"' (Schlesinger and Kinzer, 2005, p.241). Three opposition parties, the Christian Democrats, the Revolutionary Party and the MLN, jointly demanded that Ydígoras resign. Student demonstrators began to take to the streets in protest in which nearly 20 died and 200 were injured within two days. The U.S. became alarmed due to the growing public support towards the overthrow of Ydígoras. President John F. Kennedy approved a "pacification program" aimed at the rebellious provinces of Zacapa and Izabal. With American help, Ydígoras was able to defeat the revolt. They killed and jailed hundreds of students, labor leaders, peasants, professionals and ex-soldiers (Schlesinger and Kinzer, 2005). The Catholic Church even came out against Ydígoras, arguing that he has allowed 
for peasants to receive "“salaries that hardly permit them to avoid death by starvation"” and permitting plantation workers to live "in situations closely resembling concentration camps" (Schlesinger and Kinzer, 2005, p.242). Ydígoras' relationship with the U.S. began to deteriorate, until Juan José Arévalo "who led Guatemala from dictatorship to democracy in the 1940s" declared on November 26, 1962 that he was running for the presidency (Schlesinger and Kinzer, 2005, p.243). The U.S. was displeased by this development, especially given the fact that Ydígoras said he would let Arévalo return from Mexico to run for president. In order to keep Arévalo from becoming president and getting rid of the weak Ydígoras, another coup occurred. An American journalist disclosed that President Kennedy "chaired a secret meeting in early January 1963 which authorized a coup against Ydígoras” (Schlesinger and Kinzer, 2005, p.243). Ydígoras awoke with an American made tank parked on his front lawn and was forced to surrender his power to Minister of Defense Enrique Peralta Azurdia, the U.S. approved successor.

General Peralta Azurdia abandoned nearly all efforts to assist the many impoverished people in Guatemala and instead chose to militarize the country even further. He trained army squads to track and kill guerillas. Unlike Ydígoras, Peralta Azurdia turned down the assistance of Special Forces "Green Beret " troops, despite the relentless insisting by the U.S. Additionally, he promised to bring back elections in 1966. Liberals and anti-military activists rallied behind the centrist politician, Mario Méndez Montenegro. Four months before the election, Mario Méndez Montenegro was found dead in his home. Authorities declared it as a suicide, but that has been widely debated. He was replaced by his brother, Julio César Méndez Montenegro, who won the election. The military quickly tried to oust him, but backed down under American pressure. But, 
eventually the Guatemalan army was able to force the weak and frightened Méndez Montenegro into giving them greater control. This worked in the favor of the U.S. because the change in power made it possible for Americans to implement the U.S. Green Beret soldiers in Guatemala. The U.S. provided $\$ 6$ million in aid to Guatemalan armed forces under the Military Assistance Program (MAP) along with $\$ 11$ million in American military equipment. Under the presidency of Méndez Montenegro and the involvement of the Green Beret soldiers, thousands of people were killed, few being actual guerrillas. Political assasination on a mass scale became the new norm in Guatemala. The majority of those killed were middle-class professionals that supported Arévalo and Arbenz (Schlesinger and Kinzer, 2005). Four months after Méndez Montenegro took office, the New York Times reported that "the United States had now finally found a "willing partner" in Guatemala." According to Schlesinger and Kinzer, 1966 was the year that marked the beginning of "ferocious warfare in Guatemala" (Schlesinger and Kinzer, 2005, p.247). In September 1967, Clemente Marroquín Rojas, vice president under Méndez Montenegro, was interviewed by a reporter. In this interview he revealed that a "squadron of United States aircraft piloted by U.S. personnel had flown from bases in Panama, delivered loads of napalm on targets suspected of being guerrilla haunts, and flown back to their bases without landing on Guatemalan soil" (Schlesinger and Kinzer, 2005, p.247). Additionally, United States Special Forces were leading intensive training of local personnel in anti-guerrilla warfare, interrogation of prisoners and jungle survival (Schlesinger and Kinzer, 2005). The U.S. was also providing assistance to the Guatemalan national police force, allocating more than \$2.6 million from 1966 to 1970 for police instruction and equipment (Schlesinger and Kinzer, 2005). The U.S. helped increase the Guatemalan police force from 3,000 to 11,000 men. 
Right wing terror squads were running rampant throughout Guatemala. They killed the beauty queen and former Miss Guatemala, Rogelia Cruz Martínez, for her anti-government views. In reaction to this, leftist guerrillas decided to attack the United States military, claiming they were "responsible for the surge of savagery in their country" (Schlesinger and Kinzer, 2005, p.248). They killed Lieutenants and American ambassadors. The following years included further extermination strategies for the opposition and increasingly dictatorial leadership. Murders and disappearances reached unprecedented levels, as the U.S. continued to support and fund the Guatemalan government. In 1970, a large oil reserve was found in Guatemala, which provided 10 percent of the annual needs of the U.S.

By the 1980s, the 14,00 member Guatemalan armed forces had become increasingly wealthy. It had its own bank, ran investment funds for its members, and launched industrial projects. Schlesinger and Kinzer explain that military leaders had a goal of essentially destroying the political center. They labelled anyone that did not support the regime as a leftist and therefore an enemy.

As right wing terror squads were raiding the mountains of Guatemala, killing innocent civilians, more guerrilla groups began to pop up. The main groups being the Guerrilla Army of the Poor (EGP), Rebel Armed Forces, (FAR) the PGT a militant wing of the Communist party and the Revolutionary Organization of the People in Arms (ORPA). According to Schlesinger and Kinzer, the guerrillas traced their lineage directly to Operation Success. The quality of life for Guatemalans during the 1980s was nowhere near the level of the Arbenz-Arévalo years. The World Bank released a 1978 report stating that 10 percent of Guatemalan landowners owned more than 80 percent of the land. In rural areas, 15 percent of people had access to piped water, 
four percent had access to electricity. One third of the rural population was undernourished. Guatemalans were increasingly dying not only from the bullets and bombings of war, but from the scarcity of medical care and from malnutrition. 83 of every 1,000 children born did not survive the first two years of life. The violent 1954 coup was a "forcible interruption of the Guatemalan political process" (Schlesinger and Kinzer, 2005). The coup, according to Schlesinger and Kinzer, showed other countries that the U.S. was more interested in allies who didn't ask questions rather than democratic ones. Peaceful reform was put on hold as dictators were built up and encouraged by the influx of U.S. military aid. Activists saw no possibility of producing change through elections, so they turned to guerrilla warfare.

\section{Gender-based Violence pre and during Civil War}

According to Carey and Tores, the femicide we see in Guatemala today is a result of the "systemic impunity" that was cemented during the Civil War in which terror forced a social acceptance of mass murder. They argue that femicide has become further accepted as the postwar peace process leaves the violence unresolved. The Civil War, also known as La Violencia (the violence) normalized violence and rape, with many experts arguing that it was the origin for femicide and Guatemala's complicity in it (Carey and Tores, 2010). During the civil war, the military and other security forces committed 99 percent of the sexual crimes against women, but have never been brought to trial. Carey and Tores argue that we cannot pin the Civil War as the sole reason that a femicide exists today, we have to recognize the historical trend of violence against women in Guatemala. Under the dictatorships of Manuel Estrada Cabrera (1898-1920) and General Jorge Ubico (1931-1944), who the U.S. supported, women were consistenly victims of whippings, beatings, rape and muder. Douglas Hay (1992) argues that "state violence and 
private violence are reciprocal and reinforcing" (Carey and Tores, 2010). Men assumed ownership over women's bodies and the dictators reinforced "gendered terror" through their indifference toward sexual aggression. Gendered terror provides "an outlet for male frustrations that did not challenge the state and perpetuated a sense of fear and intimidation that regimes used to keep people in line" (Carey and Tores, 2010). Women were expected to be "docile producers and reproducers" and if they weren't they could be beaten (Carey and Tores, 2010). This was reinforced by a judicial system that did not act upon the violence against women, but instead let men get away with very short sentences or no time served at all. Another important historical factor to mention is that it was customary law in Mayan communities that men have a right to hit their wives and children. Women were "outlets for male aggression" and a way in which to maintain the patriarchy (Carey and Tores, 2010). If women used violence, they were seen as immoral or "savage cave-dwellers" who "drank the blood" of their antagonists"' they were made to be inhuman (Carey and Tores, 2010). Violence was to only be accepted if it were done by a man, and that is certainly a factor in the current femicide in Guatemala. Even though Arévalo and Arbenz spoke of social equality and justice, sexual violence was still very prominent under their administrations. Forster (1999) explains that “"a pervasive acceptability of hateful acts toward women seeped into work, politics, and economic change"' (quoted in Carey and Tores, 2010)

During La Violencia, Guatemalan armed forces practiced their counterinsurgency through previously established gender roles. They would display images of Ladino female guerrillas that did not follow the typical gender norms in public service ads and publish cadaver reports in the newspapers. In these ads, the point was to show that women were so naive and they required 
guidance, otherwise they would be drawn in by Marxist ideologies. These ads made women become a threat, their main roles were teachers and caregivers, therefore they could manipulate the minds of susceptible youth. The ads were suggesting to the (male) public that women needed to be tamed and controlled. Carey and Tores argue that once women became associated with being a threat to society, they became dispensable and thus were warranted victims of state sponsored violence. This was a way in which violence against women became normalized and justified, underpinning the femicide we see today (Carey and Tores, 2010). These counterinsurgency ads emphasized that anti female behavior, communism or gang involvement today were a justification for social cleansing. Since society accepted that it was a public violation for women to transgress gender norms, society also has condoned the violation of any citizen that transgresses (Carey and Tores, 2010).

The violence women faced, particularly Mayan women, is gut wrenching. Through interviews, Mayan refugee women explained how they were witnesses to countless rapes, public eviscerations of pregnant women, the burnings of alive persons in places of worship and public decapitations. Often, the bodies of the victims would be hung for everyone to see, which Carey and Tores argue "is evidence of the armed forces' public defilement of life, and particularly indigenous life, during La Violencia." Before mass assassinations, women were raped in front of loved ones and community members, with 90 percent of all these rape victims being Mayan women (Carey and Tores, 2010). There was dramatic underreporting from the newspapers of the mass murders during the civil war, which can be seen as an acceptance of the murder of Maya. Rape became a tool used for torture because of the way in which it can shame and violate both a woman's character and body. Parastate forces would also deface the bodies to make sure that the 
viewer's attention would be towards the acts of torture. According to Sylvanna Falcon this is known as "national security rape"and "is a result of the hypermasculinization of a militarized environment in which rape becomes a tool to shame women and men" (Carey and Tores, 2010).

\section{Conditions Open for Drug Trafficking}

In December of 1996, Guatemala began to emerge from their 36 year long civil war with the signing of peace accords between the umbrella guerilla organization Guatemalan National Revolutionary Unity (URNG) and the government. The peace accords were meant to cut the military and reform and rebuild a civilian police force. The military was cut from 44,000 soldiers in 1997 to 16,000 in 2009. According to Espach et al., establishing an effective national police force was met by many obstacles including no political commitment, a lack of consensus among elites and human rights groups and inconsistency in administration. In the early 2000s, it was clear that Guatemala, a country with over 1,000 miles of border and coastline and nearly 14 millions citizens had "no persistent, effective police or security presence in control in the majority of its territory" (Espach, et al. 2011). With the combination of a crippled economy and little fear of government interference, drug trafficking began to thrive throughout Guatemala.

The war created conditions in which people were constantly fearing for their lives. An estimated 500,000 to 1.5 million civilians left the country, many to the U.S. (Ewing, 2018). For those that left to the U.S. many settled in Los Angeles and became involved in the extensive gang networks there. California adopted a law that required "the deportation of foreign criminals sentenced to more than a year in jail" (Ewing, 2018). One of the main issues for Guatemala was that policy specified that the crimes committed in the U.S. would not be shared with the country the criminal was being deported to (Ewing, 2018). Guatemala had no idea the type of criminals 
that were being sent back to their country and therefore could not implement any policy to deter this type of crime. Deportations continued to rise in the U.S. and by 1996, nearly 3,600 gang members were being deported to Guatemala every year (Ewing, 2018). Historically, Guatemala had never had a gang presence within the country, but with the increase in deportations from the U.S., gang membership began to rise. According to Ewing, Guatemalan gangs mainly targeted youth who had very few options other than to join due to the fragmented state that "provided very minimal security support, minimal education and few prospects of employment in the years following the war." The Civil War left Guatemala filled with weapons and a population of uneducated young men with "few marketable skills other than the ability to handle a gun” (Brands, 2011).

Kurtenbach argues that the war had extreme consequences for youth socialization and transitions to adulthood. Families and primary social networks were torn apart by the war due to mass migration, displacement and violence. These young people during the war had no sense of stable social relations (Kurtenbach, 2012). In the second half of the war, nearly 50 percent of refugees consisted of children and adolescents and between 100,000 and 500,000 children became orphaned (Kurtenbach, 2012). Schooling was also greatly affected, public resources were being spent on the war instead of on education. There was a significant focus on recruiting children into the armed forces and paramilitary organizations. In 1995, 35 percent of Guatemala's fifteen year olds were classified as illiterate, and 44.5 percent had only three years of schooling. Youth gangs were seen as a welcoming and safe space in which they felt a sense of solidarity and belonging. According to Kurtenbach, youth violence in Guatemala is a result of the dysfunctional families and a failed school-to-work transition. 
In Guatemala today, very few people that are responsible for the violence and homicides are brought to justice. The International Commission against Impunity in Guatemala (CICIG) (an independent international organization that stemmed from the request by Guatemala for help from the UN after the peace accords and a rise in illegal armed groups) (Schneider, 2019) reported in 2006 that $95 \%$ of murders were never solved(Ewing, 2018). In 2019, former President Jimmy Morales decided to shut down the CICIG. Morales' decision to not renew the CICIG resulted in domestic and international outcry. They are responsible for prosecuting serious crimes, combating illegal armed criminal networks and overall supporting the rule of law. According to Breda, in September of 2018, the CICIG donors' group aka the G13, released a joint statement expressing regret over the government's decision, but the U.S. did not sign. Breda explains that this choice of the U.S. was a product of an "effective influence campaign" to turn U.S. politicians against the commission through intense lobbying in Washington by Guatemalan business figures and politicians (Breda, 2019). They used unproven allegations that "Moscow had penetrated the commission's 2015 invesitgations against the Bitkov family" that fled to Guatemala due to Russian persecution (Breda, 2019). They were accused of securing residency papers through corrupt means. This greatly helped the campaign against the CICIG with the U.S. Congress. Not only that, but President Morales gained favour from the Trump Administration by moving the Guatemalan embassy in Israel to Jerusalem from Tel Aviv in February 2018 (Breda, 2019). The U.S. had the opportunity to place pressure on reinstating the CICIG, but instead the Trump Administration looked the other way as Guatemala moved their embassy in Israel. The U.S. was one of the commission's main donors giving nearly $\$ 45$ million in contributions, but rather than stand with the others in the public outcry, they "chose not to push back" (Breda, 
2019). According to a recent CICIG report, criminal networks have already begun reviving techniques for obstructing judicial investigations (Breda, 2019). A spike in impunity rates has been the result, rising to 94.2 percent for homicide cases in 2018 (Breda, 2019). Even though this is public data that the U.S. is aware of, there is no action from the current administration to support the reinstatement of the CICIG. According to Breda, he predicts that with the exit of CICIG, high level officials and politicians will take advantage of weaker oversight and return to "patterns of corruption and state collusion with drug trafficking and other criminal organisations that multiple CICIG cases uncovered" (Breda, 2019).

Currently, the Guatemalan government has been unable to suppress criminal activity, which has led to Guatemalans becoming very skeptical as to whether or not the current system can provide them with "basic human security" (Brands, 2011). For instance, in 2005, indigenous Guatemalans that faced genocide during the Civil War, refused help from the army after disastrous floods and mudslides (Brands, 2011). Due to persistent violence and corruption, there is a significant amount of distrust in the government. According to a study done by USAID, 86\% of Guatemalans surveyed said they felt that "the level of insecurity facing Guatemala presents a threat to the future well-being of the country" and $45 \%$ said that "insecurity poses a threat to their own personal security" (Brands, 2011). There is very little confidence that the government can protect its citizens and extinguish the rampant violence the country faces. Today, this sentiment is expressed even more due to the dismantling of CICIG. Instead, there has been a rise in a trend known as "social cleansing" in which local vigilantes are taking the violence and corruption into their own hands. According to Kurtenbach, the increasing levels of violence we see in Guatemala is a result of state repression and zero tolerance strategies that criminalize 
gangs and also marginalized youth. This in turn had led to an increase in gang members rarely being jailed, but rather "preferred victims" of the vigilantes.

\section{Human Trafficking in Guatemala}

According to David Jr. Carey and Garbriella Tores (2010), women in Guatemala today, are killed at similar rates as the 1980s during the genocidal Civil War. More than five thousand women and girls have been brutally murdered in Guatemala since 2000. Bodies cover the streets, ravines and the media. Carey and Tores explain that "images of murdered women and girls are so commonplace that each new death risks becoming a footnote to illustrate a rising death toll.” They have labeled this as a femicide epidemic that is a reflection of the normalization of violence against women in Guatemala (Tores \& Carey, 2010). This normalization of violence against women took place during the Civil War to support the patriarchy and maintain dictatorships and democracies. Today, it is clear that Guatemala has an engrained macho culture where men need to be tough and aggressive leaders. This along with extensive sexual abuse within the home, are some of the biggest drivers of trafficking (Moloney, 2016). Often, human trafficking begins with domestic and sexual violence by fathers and stepfathers, a common situation in Guatemala (Moloney, 2016). This type of violence leads children to run away from home and typically become victim to sexual exploitation by traffickers. Gender-based violence became femicide when peacetime governments like Arbenz, became too weak to control paramilitary powers (Tores \& Carey, 2010). The findings of Tores and Carey are connected with the research of Louise Shelley (2010). Shelley presents persuading arguments regarding the connection between human trafficking and civil war. Though Shelley is not specifically looking at Guatemala, the same arguments can be applied. In her research she argues that clear links are evident between 
conflict regions and labor trafficking. She specifically looks at trafficked laborers in Uzbek, Kyrgyz, and Tajik, all countries that have had civil wars or conflict (Shelley, 2010). She continues to explain that a generation of Tajiks were deprived of education and had no possibility of employment in their country, similar to the case of Guatemala after the Civil War. Poverty is one of the main drivers for sex trafficking in Guatemala, three in five people live on less than \$3.10 a day (Moloney, 2016). This implies that sex trafficking should be seen in all poor countries, but that is not the case. Sex trafficking arises out of wartime and post-wartime societies in which populations are vulnerable and face an increased risk for trafficking and exploitation. Traffickers "exploit this tragic humanitarian situation to target refugees, forced migrants and internally displaced persons"(Catholic News Service, 2017). Traffickers are targeting poor, uneducated and unemployed women, providing them with false promises of earning money from modelling or waitressing (Moloney, 2016). Shelley also argues that the rise of conflict in Afghanistan has exasperated sexual and labor trafficking between Tajikistan and Afghanistan (Shelley, 2010). She goes on to describe how in Nigeria, after the civil war in the late 1960s, major organized crime groups began to develop vastly throughout West Africa. A similar situation occurred in Guatemala as gang participation surrounding drug trafficking increased.

Throughout Guatemala, criminal organizations took advantage of the institutions weakened by the Civil War, along with the rampant poverty and social alienation that left many with no other choice than to become involved in criminal activity. According to Brands, "drug traffickers, youth gangs, and organized crime syndicates generally lack the coherent ideological or political program often associated with an insurgency" yet they have still managed to weaken 
the state and establish dominance over many parts of the population. They aim to not overthrow the established government, but instead to "take control of a city, one neighborhood-or even one block- at a time" (Brands, 2011). Essentially they are working to corrode the authority of the state, yet still use the government to their advantage through hefty payoffs. In 2007, then- Vice President Eduadro Stein stated that "criminal elements" controlled six out of 22 Guatemala departments. Nearly $\$ 1$ billion of drug money making its way through Guatemala is used to bribe government officials (Brands, 2011). Cartels also pay small-town mayors in order to set up airstrips, they bribe judges, police, military officials and border guards in order to avoid government surveillance and prosecution. According to Brands, when plata (money) cannot persuade the authorities, then plomo (lead) "is used to batter them into submission." Essentially, these criminal organizations are making it so that state authority has no control over their operations. They have been able to build their own infrastructure through the accumulation of control over various cities and towns especially along the border, and have moved into human trafficking operations. Violent youth gangs represent the third major criminal group present in Guatemala. The Maras are larger, more sophisticated groups that have tens or even thousands of members throughout multiple countries. They use their international connections to smuggle arms as well as participate in human trafficking. They have strong connections in Mexico as well as the U.S. where tens of thousands of members across more than 40 states exist (Brands, 2011). According to a USAID official, most of the mareros are victims of poverty, violence, unstable family life and are uneducated, "They have no realistic hope of getting anywhere in the modern world" (Brands, 2011). 
Throughout the Northern Triangle, it is estimated that " 30,000 people in Honduras, 47,000 in Guatemala, and 16,000 in El Salvador are living in conditions of enslavement as defined within the traditional framework of human trafficking" (Boerman and Golob, 2020). There has been some effort from the Guatemalan government over the years to combat human trafficking, including in 2009 the passing of La Ley Contra la Violencia Sexual, Explotación y Trata de Personas (The Law Against Sexual Violence, Exploitation and Trafficking in Persons). The main objective of this was to "...prevent, repress, punish and eradicate sexual violence, the exploitation and trafficking of persons, the care and protection of their victims and to compensate for the damages caused" (Congress, Guatemala, 2009). As we can see from current statistics, this goal has not been achieved. Recently, Guatemala released its 2018-2022 National AntiTrafficking Plan. This plan urges for increased investigation and prosecution of trafficking cases, increased victim services, improving access to the Mayan community and greater outreach outside of Guatemala City (Boerman and Golob, 2020).

According to the 2018 Trafficking in Persons Report, the Guatemalan government didn't demonstrate increased efforts to prevent or prosecute cases. The previous reporting period shows that the government did not increase efforts to protect victims, in fact they decreased protection efforts by identifying only 371 victims in 2018 and 316 in 2017, compared to 484 in 2016 and 673 in 2015 (Boerman and Golob, 2020). According to the 2019 Trafficking in Persons Report, the government prosecuted and convicted fewer traffickers and they "did not address underlying problems in the nation's shelters providing for child trafficking victims; referred only 64 percent of victims to care, and specialized victim services remained inadequate." Based on the report, corruption and complicity remain significant concerns. According to the U.S. State Department 
in Guatemala, criminal organizations such as gangs, are exploiting girls in sex trafficking and coercing young males in urban areas to sell and transport drugs or commit extortion (Boerman and Golob, 2020). In 2016, the United Nations Human Rights Council (UNHRC) explained that when children and women are recruited via force into gangs, they become "locked into dangerous, exploitative and dehumanizing situations" where leaving is not an option (Boerman and Golob, 2020). According to Boerman and Golob, children and youth are at even higher risk for being coerced into gangs due to a lack of protective adult presence, especially a male presence. As discussed earlier, one of the main results of the war was mass migration and displacement in which between 100,000 and 500,000 children became orphaned (Kurtenbach, 2012). The 2019 report states that foreign child sex tourists, coming from mainly Canada, the U.S. and Western Europe as well as Guatemalan men "patronize child sex trafficking victims for commercial sex acts" (Department of State, 2019). Traffickers continue to exploit Guatemalan men, women and children in forced labor within the agriculture and domestic service industries in Mexico, and the U.S. Indigenous Guatemalans, including children are especially vulnerable to forced labor and exploitation. Children are exploited regularly by traffickers, being forced into begging and street vending. Criminal organizations such as gangs, are exploiting girls in sex trafficking and coercing young males in urban areas to sell and transport drugs or commit extortion (Department of State, 2019). Additionally, police, military, and elected officials were placed under investigation for paying children for sex acts, facilitating sex trafficking and protecting sex trafficking venues (Department of State, 2019).

According to Boerman and Golob, Northern Triangle countries are male dominated societies "in which an exceedingly high percentage of child, adolescent and adult females are 
subjected to the psychologically, physically and sexually coercive and violent behavior of males" that act with impunity. Boerman and Golob explain that gang members tend to be the "most hyper-masculinized of the hyper-masculinized" and the most violent. The situation in Guatemala today is a replica of the normalized violence during the Civil War. They see women as "their women" essentially their property. Gang members risk beatings if they allow women to openly defy them. Gangs use terror strategies as a way in which they are able to establish control over territories, criminal markets and the population. Similar to during La Violencia, Boerman and Golob refer to a recent study that showed gang members are still raping and torturing girls and leaving their mutilated and dismembered bodies in public. In doing this, they are demonstrating their dominance and instilling fear in the community (Boerman and Golob, 2020). In one of Boerman and Golob's interviews an anonymous UN Representative stated that "For girls in gang-controlled areas, reaching sexual maturity is a risk factor” (Boerman and Golob, 2020). One of the risks is being agarrada (grabbed), in which a young girl is abducted and subjected to sexual violence and then most likely disappeared or murdered. Another risk is being a gang leader or member's Jaina which “is often misinterpreted as synonymous with "girlfriend"' (Boerman and Golob, 2020). Once a girl is made a Jaina, or targeted as one, they are then considered property of the gang in which the gang has complete control over every aspect of their life and are usually coerced into criminal activity (Boerman and Golob, 2020). In another one of Boerman and Golob's interviews with a UN Special Rapporteur, he found that "“The most common form of extreme extortion of sexual and other services described by the interlocutors involves forcing them (young females) to provide sexual services to gang members in prisons"'(Boerman and Golob, 2020). Women and their families are threatened with violence or 
death in order to make them comply. These women have no way out. There is significant fear associated with reporting gang related sexual and gender based violence, along with the idea that reporting is useless given that gangs are known for paying off cops. Therefore, the majority of victims do not seek assistance.

Brands explains that in order to defend against the increasing criminal networks in Guatemala, the government needs to synchronize police and military programs as well as work towards social reform, institution building and economic development. But, one of the many problems facing the government is that historically the Guatemalan government has turned against its citizens, so there is significant distrust and resistance in allowing the military into domestic security matters, even though the police are overwhelmed. As a result of the Civil War, poverty and an influx of gang violence, as well as heightened gender based violence are working together in order to make crime attractive to Guatemalan youth. The vast corruption and weak government continue to undermine any countermeasures the Guatemalan government introduces, and thus poses a significant hurdle for an effective response to the rampant human trafficking crippling Guatemala. Additionally, starting in the 1960s, "the experience of fighting the violent left led to the formation of tight-knit military fraternities among officers who rose the ranks together" (Brands, 2011). The war resulted in the rise of a corrupt military elite that "used their influence and connections to snap up the best arable land, acquire favorable positions in mining and industry, divert government funds for their personal use, and engage in the drug trade and other illicit activities" (Brands, 2011). Until the government and drug cartels cut their ties, it is challenging to see a future in which human trafficking decreases in Guatemala. 


\section{Immigration Today-An Implication of the War}

Guatemalan migrants making their way to the U.S. border in hopes of a better and safer

life face obstacles every step of the way. Their journey to the border is often a tumultuous and dangerous one, with relief rarely being found after stepping foot on U.S. soil. Often, they are met with family separation, third country agreements, deportation and long detention periods. Additionally, they face racist, anti-immigrant rhetoric. When discussing immigration, it is important to recognize the push and pull factors that drive people to immigrate. For the case of Guatemala, the push factors consist of femicide, human and drug trafficking and an overall unstable and dangerous environment. The pull factors urging Guatemalans to migrate to the U.S. are hopes for a more stable and safe life. Not only that, but in the U.S. there is a built in demand for unskilled labor that often drives immigrants to migrate.

Large scale immigration to the U.S from Guatemala is one of the main implications of the Civil War. The number of Guatemalans that migrated to the U.S. both legally and unauthorized during the war rose from 13,785 in 1977 to 45,917 in 1989 (Jonas, 2013). The majority of those seeking refuge in the U.S. were indigenous Maya and ladino (mixed) as they were the main victims of the war. During the late 1970s, in which the war was focused in the western Mayan highlands, the first large-scale migration began consisting of mainly Mayan refugees. Thousands ended up in United Nations refugee camps in southern Mexico. Some of the displaced went to the United States to seek asylum from political or ethnic persecution, but were not granted refugee status in Mexico or the U.S. According to the Guatemalan Army's reports, their operation destroyed 440 highland villages from 1981-1983. Nearly 150,00 (primarily highland Mayas) were killed or disappeared in the early 1980s with 200,000 being the total from 
1954-1996. 1 million Mayan villagers were internally displaced, and nearly 200,000 fled to southern Mexico with 46,000 going to the camps and the other 75 percent outside the camps (Jonas, 2013). Even though Mayan and ladinos were clearly being persecuted by their government, they were still denied refugee status. According to the 1951 U.N. Convention, which is "the centrepiece of international refugee protection today" a refugee is someone that is "unable or unwilling to return to their country of origin owing to well-founded fear of being persecuted for reasons of race, religion, nationality, membership of a particular social group or political opinion" (UNHCR, 2007). The U.S. signed onto the U.N. refugee protocol in 1967. Not only did the U.S. place Guatemala on a trajectory towards violence, they continued to neglect the problems they helped create in Guatemala by denying asylum applications. In 1984, "only 3\% of asylum applications were approved for Guatemalans and Salvadorans, compared with 40 percent for Afghans fleeing the Soviet invasion and 100 percent for Cuban asylum seekers" (The Week, 2019). Despite a genocidal civil war occuring in Guatemala, that the U.S. had direct knowledge of and assisted in, they still refused to help. René de León Schlotter, a leader of Guatemala's center left Christian Democrats, made a statement in front of the United States Congress in 1976 illuminating the reasons as to why the U.S. needs to be held accountable and share the responsibility in what Guatemala had become:

The responsibility of the United States, although indirect, is very real and serious. With its policy of supporting dictatorships, the United States has collaborated in the strengthening of these regimes and burdened our people with debts, often for the most superfluous programs. With its policy of military and police assistance, 
the United States has collaborated in the acts of repression, and consequently in the violation of human rights (Schlesinger and Kinzer, 2005, p.250).

Migration continues in this post war era due to the "severe socio economic problems, successive natural disasters, increasing social violence- and weak state, lacking the vision, capacity, and resources to resolve these problems internally" (Jonas. 2013). Additionally, several environmental disasters have occurred in Guatemala since the 1990s including two hurricanes and an earthquake. Yet, following these disasters, Guatemalans have never been granted Temporary Protected Status in the United States, despite Salvadorans, Hondurans and Nicaraguans receiving this relief. Guatemala today is still feeling the effects of the Civil War that the U.S. helped fund. They have widespread femicide, little economic opportunity and overall rampant gang violence. These are the main contributors as to why we see such significant numbers of Guatemalans trying to migrate to the U.S. So why are Guatemalans being denied at the U.S. border when we played such a significant role in the country's demise?

Currently, there is a backlog of more than 900,000 immigration court cases which in turn has resulted in very overwhelmed detention facilities under Trump's zero tolerance policy. The Trump Administration has taken the neoclassical economic approach to deter asylum seekers. The Trump Administration has chosen to raise the costs of seeking asylum and lower the benefits through actions like family separation and forcing asylum seekers to wait in Mexico for their court date. This is part of Trump's Wait in Mexico Procedure, officially known as Migrant Protection Protocols, which is also related to the new "Last-in first out" process for accepting refugee/asylee applications. This means that recently filed asylum applications will be prioritized over those that have been pending for years. According to the Trump Administration, the years- 
long waiting period encourages fraudulent claims. Previously, if someone received a "positive determination" in their credible fear interview they would be given a Notice to Appear (NTA) and a hearing date with an immigration judge. Also, the asylum seeker could be eligible for an immigration bond, allowing for their release into the U.S. while their case was pending in court (Blake, 2019). This Wait in Mexico Procedure was unveiled by former Secretary of Homeland Security, Kirstjen Nielsen in an effort to "curtail the so-called catch-and release system, in which individuals make fraudulent asylum claims knowing they will be allowed into the United States and be able to stay for years before their court appearance, which many do not show up for" (Blake, 2019). With this procedure, the credible fear interview is no longer occurring and asylum seekers are sent to Mexico with a NTA. Once they arrive in Mexico, they are then given a humanitarian visa by the Mexican government which is valid for a year. They are told to return to a port of entry within 45 days for a hearing with a U.S. immigration judge (Blake, 2019). One of the main challenges that asylum seekers face when sent to Mexico is being able to acquire legal counsel. According to Blake, it is typically unlikely that asylum seekers will find U.S. attorneys "to take on and adequately prepare their cases." Additionally, 80 percent of the 60,000 people forced to remain in Mexico "are regularly targeted for abduction and other acts of severe violence" (Blake, 2019). This last-in first out policy severely disadvantages asylum seekers that have already been waiting in the backlog. They now risk being sent back to violent and life threatening conditions “"because their cases will be further delayed and they will have even more difficulty getting witnesses and evidence to support their claims"'(Torbati, 2018). Some immigration lawyers even argue these changes have "made it harder to assemble documentation on short notice for applicants whose cases get fast-tracked" (Villagomez, 2018). If lawyers 
cannot collect enough evidence in time, their clients will not be granted asylum (Villagomez, 2018).

In fiscal year 2019, Customs and Border Patrol encountered over 977,509 people attempting to cross the southwest border. Most of these people are coming from Guatemala, Honduras and El Salvador in an effort to flee the rampant crime, violence and corruption occurring in these countries. Travel warnings have been issued by the U.S. to all of these countries, yet the Trump Administration is still trying to send asylum seekers there. The Trump Administration issued a "sweeping rule in July that prevents migrants from being granted asylum if they passed through any country other than their own before arriving in the U.S." (Narea, 2019). The Administration made agreements with Guatemala, El Salvador, and Honduras that migrants must apply for protections in these countries first, before they can come to the U.S. even though most asylum seekers today are from these countries. This has been framed "as a way to help these countries develop their asylum systems" which includes a $\$ 47$ million pledge to Guatemala (Narea, 2019). President Morales signed onto the Trump Administration "Safe Third Country Agreement" in July of 2019. Once again, political leaders in Guatemala are playing right into the hand of the U.S. and not advocating for their most vulnerable citizens. A country in which over 250,000 of its citizens have tried to flee and were apprehended at the U.S. border since October 2018 (Semple, 2019). There is widespread opposition to the agreement within Guatemala. The Constitutional Court ruled that the Guatemalan government needed congressional approval to make this agreement with the U.S. This decision occurred during the negotiations between former President Morales and the Trump Administration leading President Trump to threaten Guatemala with tariffs, a travel ban and taxes on remittances sent home by 
Guatemalan migrants in the U.S. (Semple, 2019). Guatemala does not have the infrastructure to support vulnerable refugees and asylum seekers when they can hardly protect their own citizens, yet that is not stopping the Trump Administration or former President Morales from trying to make this deal work. Current President Alejandro Giammattei was not as keen towards the "Safe Third Country Agreement," but ended up backing it as well. If he had not signed the agreement, Trump threatened to withhold all development aid for Guatemala.

\section{Alternative Explanations}

Some may argue that Guatemala was already on a path to civil unrest regardless of U.S. intervention, explaining that there is an ingrained machismo culture existing in Guatemala. Carey and Tores argue that the Civil War is not the only reason that a femicide exists in Guatemala today, but that we also need to recognize that there is a historical trend of violence against women in Guatemala. Some argue that women are seen as subordinate to men within society and that this weak female role is the reason as to why we see increasing femicide within Guatemala today. According to Golob, "This machismo phenomenon fosters a mindset of male domination, which can often lead to mistreatment of women and children at the hands of men." Jackson argues that machismo culture has created a society in Guatemala that sees women as lesser beings causing their deaths to be overlooked. He continues to argue that old cultural norms must be tackled if Guatemala wants to create a society that cares for and protects women. Yet, there are many other machismo cultures that exist and do not experience rampant human trafficking or femicide. For example, Spain has a machismo culture and also experienced a brutal dictatorship and civil war, yet they are a tier 1 country for human trafficking. The government of Spain fully meets the standards for eliminating human trafficking and are improving each year in their 
efforts to lessen its existence in their country. One may argue that there are substantial differences in the level of economic development between Spain and Guatemala, which is certainly true. But, the financial distress Guatemala is experiencing is yet another implication of the vast involvement of the U.S. in Guatemala's government and Civil War. Guatemala is experiencing these issues as a result of the U.S. engineering the overthrow of democratically elected Jacobo Arbenz and replacing him with a long line of violent dictators that the U.S. also supported through funding, weapons and training. This normalization of gendered violence and rape occurred during the 36 year long Civil War. According to Sylvanna Falcon, rape is a weapon of war, it is also known as "national security rape" and is a result of hypermasculinization of a militarized environment (Carey and Tores, 2010). Falcon also argues that "rape and sexual assualt are rationalized in wartime due to the construction of the (racialized) enemy" which in the case of Guatemala was mainly guerillas and women, particularly indigenous women (Falcon, 2001). This normalization of violence occurred during the Civil War in order to uphold the patriarchy while maintaining dictatorships and democracies (Tores \& Carey, 2010). This mindset has carried over into postwar Guatemala as gangs continue to attempt to take control of the government and local authorities through hefty payoffs and scare tactics. Using violence as a weapon against women and seeing their bodies hanging in the streets became increasingly normalized during the war to the point that we still see it occurring today. The femicide occurring in Guatemala today is a direct reflection of the normalization of violence towards women during the war. The terror during the Civil War forced a social acceptance of mass murder.

Another explanation as to why Guatemala was already on a path towards demise is the historical wrongful treatment of indigenous peoples in Guatemala, particularly the Mayas. 
Before the war, Mayas were subsistence farmers that produced staple crops such as beans and maize. Before Arbenz was elected president, his predecessors decided to follow U.S. corporate interests and turn the economy towards producing commodities such as coffee, sugar and bananas for the U.S. market. Jorge Ubico allowed UFCO to own or lease three million acres of land and operate fifteen hundred miles of railroad, much of which was indigenous land. Also, Ubico passed vagrancy laws in which indigenous people that did not own land had to work for local landowners at least 100 days a year. Additionally, he made it legal to "murder stubborn or rebellious Indians" (Bucheli, 2008). The government claimed that the Mayas were Marxist insurgents due to their resistance to the new military dictatorship after the overthrow of Jacobo Arbenz. During the Civil War, in 1976, the Guatemala dictatorship attempted to eliminate the Maya population through building a dam in the Rio Chixoy River where the Maya Achi lived. The land surrounding the river was considered the most fertile in all of Guatemala. According to Cooper (2009), Mayans that resisted the construction of the dam were "labeled as Marxist rebels and targeted for destruction by the government's Civil Defense Patrols." In 1982, seventy women and 107 children were brought from Rio Negro to Pacoxon and then raped and killed. Months later, an additional 84 Rio Negro people were tortured and killed and 35 orphaned children were killed in Agua Fria (Cooper, 2009). All of these murders were declared as counterinsurgency activities by the Guatemalan government. The U.S. was aware of all of these murders and continued to back the genocide occuring in Guatemala. According to Cooper, countering "the U.S.-backed genocide in Guatemala, Spain, France and Sweden threw their support behind the Guatemalan National Revolutionary Unity (URNG) guerrilla movement” (Cooper, 2009). The U.S. had the choice to end their funding of the long line of violent dictators in Guatemala, but 
instead put their own interests above the lives of hundreds of thousands of people murdered during the war. All of this is evidence as to the repeated mistreatment of indigenous peoples in Guatemala, but most of which was done to further U.S. interests. Arbenz wanted to help poor indigenous farmers by supplying them with land and hope for a better future, yet that got in the way of U.S. interest in Guatemala so he was removed.

\section{LIMITATIONS}

Initially, this paper was to solely discuss human trafficking as an indirect consequence of U.S. involvement in Guatemala, but there was just not enough data. The U.S. did not start releasing the Trafficking in Persons Reports until 2000, so there is no data to show what human trafficking was like before then. One may argue that human trafficking actually did not increase because we do not have the data to prove it. Not only that, but there is no data of human trafficking during the war either. But, my argument is that human trafficking grew out of the expansion of gang membership and drug trafficking. This is seen through the creation of gang networks after Guatemalans seeking a better life in the U.S. were exposed to gang violence and deported back to a country with little to no economic opportunity. As gangs spread throughout Guatemala and the rest of Central America, so did human trafficking networks along with normalized gender based violence as a result of the Civil War.

\section{CONCLUSION}

On June 27th, 1954 Jacobo Arbenz was democratically elected as president and ready to bring social and agrarian reform to the people of Guatemala who desperately needed it. His ideas went against the American conglomerate within Guatemala, the United Fruit Company. UFCO owned the majority of land in Guatemala and controlled it's railroads, wharves, shipping and telegraphs. 
Additionally, UFCO was well connected to the Eisenhower administration. When Arbenz won the presidency, this was not to the liking of UFCO officials. Under the Ubico dictatorship, UFCO was allowed to do whatever it pleased in Guatemala. But, as soon as Arbenz began to enforce his plan of social agrarian reform, UFCO labeled him a communist. From the beginning, Arbenz made it clear that he wanted Guatemala to cut ties with UFCO. He expropriated 386,901 acres acres of uncultivated land that belonged to UFCO to poor farmers. He believed that unequal land distribution was one of the leading causes hindering Guatemala's economic development. He also planned on building a highway to the Atlantic in order to end UFCO's monopoly on Guatemala's foreign trade given that they owned 887 miles of railroad tracks in Guatemala spanning across the whole country. UFCO had a stranglehold on Guatemala and Arbenz attempted to put an end to it. But, UFCO did not go away quietly. The U.S. press began printing stories about torture and mass arrests occurring under the Arbenz regime, claiming Guatemalans were living in a Communist reign of terror. With the backdrop of the Cold War, the U.S. was showing that they could defeat the Communist regime they claimed existed in Guatemala. UFCO continued running a smear campaign against Arbenz, building up American fears which eventually led to a CIA backed coup in 1954. After the coup, the U.S. put Castillo Armas into power and provided him with $\$ 80$ million dollars. Armas reversed everything that Arbenz was working towards and nearly drove all the peasants that had benefited from the agrarian reform off their new land. He, like the rest of the dictators that followed him, was very focused on censorship and even withheld elections from taking place. But, the U.S. was invested in him. This was the first time a "democratic" government was replacing a "communist" one and the 
U.S. had to show that Guatemala could be an example of democratic change, even though Armas was not actually elected by the people like Arbenz was.

In 1960, the Civil War began as growing divides led to a group of armed insurgents known as Unidad Revolucionaria Nacional Guatemalteca (URNG) starting an unsuccessful uprising against the military regime that followed the coup. Beginning with the 1954 coup and putting Armas in power, the U.S. laid the foundation for a long line of military dictators to take power in Guatemala. The U.S. put hundreds of millions of dollars into the dictatorships following the 1954 coup and during the 36 year long Civil War. They played an important role in nearly every stage of the war. They provided them with extensive military training, weapons and U.S. soldiers on the ground. The U.S. helped bring to power some of the worst dictators in history, including Rios Montt whom Ronald Reagan referred to as "a man of great integrity" and "totally dedicated to democracy" (Grandin, 2013). Montt wanted to "drain the sea" of the guerrilla movement and largely targeted indigenous peoples. He led the "Scorched Earth" military strategy in which more than 70,000 people died and went missing. He killed children and elderly who could not have possibly been guerrillas. Reagan provided financial support, military advising and lifted the U.S. embargo that Jimmy Carter had placed to pressure Guatemala to stop the abuses. Reagan was not making these statements and assisting Montt without knowing the human rights abuses occurring in Guatemala. He was well aware of the large scale killings of indigenous people committed by the Guatemalan army. Instead of cutting off funding to the Guatemalan government and admitting that those in power were leading a genocidal war, the U.S. continued their support. They reinforced the continuation of this war and 
the demise of the country. With U.S. support, Montt continued attacking indigenous communities and by the end of the war, nearly 200,000 people were killed and 45,000 "disappeared."

After the Civil War, the country was in shambles. There was no economic opportunity, but rather rampant violence for those who survived. Most had no other choice but to leave in search of a better life. Many that fled to the U.S. after the war became involved in the gang networks there and would end up getting deported back to Guatemala. Guatemala never had experience with gangs, but as deportations began to rise, so did gang membership within Guatemala. Youth were the main targets of Guatemalan gangs because they had few options other than to join. They were mostly orphans, uneducated with very few prospects of employment. As gang membership increased and spread throughout Guatemala and Central America in general, so did human trafficking. With the advantage of international gang networks throughout Central America and within the U.S. with gangs such as the Maras, human trafficking took off. They would target poor, vulnerable girls and women with promises of economic opportunity through careers such as modelling or waitressing. These new criminal organizations took advantage of the weakened institutions after the Civil War along with the poverty and social alienation that left people with no other choice than to get involved with criminal activity.

During the war, gender based violence became increasingly normalized and has carried over into the femicide taking place in Guatemala today. The violence that women experienced, particularly Mayan women is horrifying. They faced countless rapes, pregnant women being eviscerated publicly, women being burnt alive and public decapitations. Their bodies would be hung for everyone to see as evidence of the armed forces' disregard of life, especially indigenous life. Mayan women made up 90 percent of all rape victims during the Civil War. The judicial 
system did not act upon any of the violence that women were facing, but rather let men get away with little to no time served at all. Most of the time, local authorities as well as the government were being paid off, which continues to be the case today with drug and human traffickers. Criminal organizations are continuing to exploit girls in sex trafficking at heightened numbers as well as coercing young males to sell and transport drugs. Women and children that have been recruited by these gangs are becoming locked into dangerous and abusive situations and are unable to leave. This is largely a result of the state that the U.S. funded Civil War left Guatemala in.

Guatemala still feels the effects of the Civil War today. They face a national femicide, exceedingly high rates of human trafficking and drug trafficking, as well as an increase in migration to the U.S. The economic hardship and violence that Guatemalans continue to face today is once again leading them to seek refuge and a better life in the U.S. Guatemala needs to do better in order to put an end to rising rates of human trafficking and femicide. Policies need to be put into place and enforced. Prosecution needs to increase, people need to be held accountable. The U.S. also needs to realize their role in the demise of Guatemala and how they were pivotal actors that brought the country to where it is today. The problems that Arbenz was attempting to alleviate within Guatemala are even worse now than they were before. The Guatemalan government needs to focus on greater socio-economic opportunities and combat the corruption that is so heavily present within local and state authorities. Educational opportunities as well as services for victims of human trafficking and domestic violence need to be expanded. Additionally, the U.S. needs to recognize the history behind why so many Guatemalans are trying to enter the U.S. and loosen our immigration protocol. The Trump administration has 
painted a picture that Guatemalans trying to enter the U.S. are all violent criminals and sex traffickers, when in reality they are just people having to flee a war torn country that the U.S. perpetuated. Rather than just deporting Guatemalans back to an unsafe environment and cutting aid, the U.S. government needs to realize the push factors that are sending them to the border. The historical involvement of the U.S. in Guatemala has caused instability and inequality within the country today. They funded a war and upheld dictators that committed countless human rights abuses. This war led to a country in which there was nearly nothing left, no economic opportunity, just greater gang membership, human trafficking and normalized gender based violence that we continue to see today. Rather than accepting this and creating greater aid for Guatemala and programs that could assist the most vulnerable such as the Maya, the current administration continuously threatens to deny any aid at all if Guatemala does not comply with the "Safe Third Country Agreement." Trump is taking advantage of migrants trying to flee Guatemala for a better life and using their futures as bargaining chips. In return for expanding the agreement, he has set aside 10,000 H2-B temporary non-agricultural work visas for Guatemalans, Salvadorans and Hondurans. We must do better. An apology from President Clinton in 1999 is not enough. 


\section{Bibliography}

Barrett, D.M. (2011, August 3). "Congress, the CIA, and Guatemala, 1954." Central Intelligence Agency, Central Intelligence Agency. www.cia.gov/library/center-for-thestudy-of-intelligence/kent-csi/vol44no5/html/v44i5a03p.htm.

Blake, J. (2019, April 15). What the New "Wait in Mexico" Procedure Means for Asylum Applicants. Retrieved from https://www.nolo.com/legal-updates/what-does-the-new-waitin-mexico-procedure-mean-for-asylum-applicants.html

Boerman, T. \& Golob, A. (February 3, 2020) Gangs and modern-day slavery in El Salvador, Honduras and Guatemala: A non-traditional model of human trafficking, Journal of Human Trafficking, DOI: 10.1080/23322705.2020.1719343

Bracken, A. (2016, December 29). Why you need to know about Guatemala's civil war. Retrieved from https://www.pri.org/stories/2016-12-29/why-you-need-know-aboutguatemalas-civil-war.

Brands, H. (2010). Crime, violence, and the crisis in Guatemala: a case study in the erosion of the state. Place of publication not identified: Strategic Studies Institute U S Army War College.

Brands, H. (2011) Crime, Irregular Warfare, and Institutional Failure in Latin America: Guatemala as a Case Study, Studies in Conflict \& Terrorism, 34:3, 228-247, DOI: $\underline{10.1080 / 1057610 X .2011 .545937}$

Breda, T. (2019, September 3). Curtain Falls on Guatemala's International Commission against Impunity. Retrieved from https://www.crisisgroup.org/latin-america-caribbean/centralamerica/guatemala/curtain-falls-guatemalas-international-commission-against-impunity Brockett, Charles D. "US Labour and Management Fight It Out in Post-1954 Guatemala." Journal of Latin American Studies. 42, no. 3 (2010): 535.

Bryjack, G. J. (2017, February 10). A lesson to learn. Retrieved from https:// www.adirondackdailyenterprise.com/opinion/guest-commentary/2017/02/a-lesson-tolearn/ 
Bucheli, M. (2008). Multinational corporations, totalitarian regimes and economic nationalism: United Fruit Company in Central America, 1899-1975. Business History, 50(4), 433-454.

Carey, D., \& Torres, M. (2010). PRECURSORS TO FEMICIDE: Guatemalan Women in a Vortex of Violence. Latin American Research Review, 45(3), 142-164.

Catholic News Service. (2017, November 28). Wars, violent conflicts main drivers of human trafficking, says nuncio. Retrieved from https://www.ncronline.org/news/world/warsviolent-conflicts-main-drivers-human-trafficking-says-nuncio

COHA. (2011, May 10). Guatemala's Crippled Peace Process: A Look Back on the 1996 Peace Accords. Retrieved from http://www.coha.org/guatemalas-crippled-peace-processa-look-back-on-the-1996-peace-accords/

Congress, Guatemala. (2009). La Ley Contra la Violencia Sexual, Explotación y Trata de Personas. http://www.sipi.siteal.iipe.unesco.org/sites/default/files/sipi_normativa/ley- 33 33 contra-la-violencia-sexual-explotacion-y-trata-de-personas_-_decreto_9-2009_guatemala.pdf

Cooper, A. D. (2009). The Geography of Genocide. United States: University Press of America. Department of State (2019). 2019 Trafficking in Persons Report. https://www.state.gov/ wp-content/uploads/2019/06/2019-Trafficking-in-Persons-Report.pdf

Dosal, P. (1993). Doing business with the dictators : A political history of United Fruit in Guatemala, 1899-1944 (Latin American silhouettes). Wilmington, Del.: SR Books.

Espach, R., Quinonez, Haering, Giron, \& Center FOR Naval Analyses Alexandria VA. (2011). Criminal Organizations and Illicit Trafficking in Guatemala's Border Communities.

Ewing, H. (2018). A Perfect Storm: How the Guatemalan Civil War, U.S. Immigration Policy and Drug Trafficking Organizations Debilitated the Guatemalan State. Vanderbilt University Thesis.

Falcón, S. (2001). Rape as a Weapon of War: Advancing Human Rights for Women at the U.S.-Mexico Border. Social Justice, $28(2$ (84)), 31-50. Retrieved May 17, 2020, from www.jstor.org/stable/29768074 
Farah, D. (1999, March 11). Papers Show U.S. Role in Guatemalan Abuses. Retrieved from https://www.washingtonpost.com/wp-srv/inatl/daily/march99/guatemala11.htm

Fisher, Z. C. (2012). American Propaganda, Popular Media, and the Fall of Jacobo Arbenz. University of Nevada, Las Vegas Theis. Available from Worldwide Political Science Abstracts. (1520338801; 201410957). Retrieved from http://stats.lib.pdx.edu/ proxy.php?url=http://search.proquest.com.proxy.lib.pdx.edu/docview/1520338801? accountid $=13265$

Golob, T. A. (2014). Human trafficking from southern mexico, honduras, el salvador, and guatemala: Why these victims are trafficked into modern day florida (Order No. AAI1555111). Available from Worldwide Political Science Abstracts. (1629329827; 201426976). Retrieved from http://stats.lib.pdx.edu/proxy.php?url=http:// search.proquest.com.proxy.lib.pdx.edu/docview/1629329827?accountid=13265

Grandin, G. (2013, May 21). Guatemalan Slaughter Was Part of Reagan's Hard Line. Retrieved from https://www.nytimes.com/roomfordebate/2013/05/19/what-guilt-doesthe-us-bear-in-guatemala/guatemalan-slaughter-was-part-of-reagans-hard-line

Jackson (n.d.) The Issue of Femicide in Guatemala. The University of Texas.

Jonas, S. (2013, March 27). Guatemalan Migration in Times of Civil War and Post-War Challenges. Migration Policy Insitute. Retrieved from https://www.migrationpolicy.org/ article/guatemalan-migration-times-civil-war-and-post-war-challenges

Kinzer, S. (2018, April 1). Efraín Ríos Montt, Guatemalan Dictator Convicted of Genocide, Dies at 91. Retrieved from https://www.nytimes.com/2018/04/01/obituaries/efrain-rios-monttguatemala-dead.html

Koeppel, D. (2008). Banana: the fate of the fruit that changed the world.

Kurtenbach, S. (2012) : Postwar Youth Violence: A Mirror of the Relationship between Youth and Adult Society, GIGA Working Papers, No. 199, German Institute of Global and Area Studies (GIGA), Hamburg

Moloney, A. (2016, June 8). Guatemala 'closes its eyes' to rampant child sex trafficking: U.N. Retrieved from https://www.reuters.com/article/us-guatemala-humantraffickingidUSKCNOYU29V 
Narea, N. (2019, September 12). "The Supreme Court Has Delivered a Devastating Blow to the US Asylum System." Vox.

Schlesinger, S., \& Kinzer, S. (2005). Bitter Fruit: The Story of the American Coup in Guatemala. Cambridge (Massachusetts): Harvard University, David Rockefeller center for Latin American Studies.

Schneider, M. L. (2019, April 11). Democracy in Peril: Facts on CICIG in Guatemala. Retrieved from https://www.csis.org/analysis/democracy-peril-facts-cicig-guatemala

Semple, K. (2019, July 28). The U.S. and Guatemala Reached an Asylum Deal: Here's What It Means. Retrieved from https://www.nytimes.com/2019/07/28/world/americas/guatemalasafe-third-asylum.html

Shelley, L. (2010). Human trafficking : A global perspective. Cambridge [UK] ; New York: Cambridge University Press.

The Week Staff. (2019, April 28). The complicated history of asylum in America explained. Retrieved from https://theweek.com/articles/837512/complicated-historyasylum-america--explained

Torbati, Y. (2018, January 31). "U.S. Immigration Agency to Review Newest Asylum Cases First in Bid to Deter Fraud.” Reuters, www.reuters.com/article/us-usa-immigrationasylum/u-s-immigration-agency-to-review-newest-asylum-cases-first-in-bid-to-deterfraud-idUSKBN1FK2Y5.

UNHCR (2007). Convention and Protocol Relating to the Status of Refugees. Media Relations and Public Information Service. Geneva.

Velásquez Gómez, I., \& Skoog, C. (2016). Human trafficking for sexual exploitation purposes in Guatemala. UNICEF and International Commission against Impunity in Guatemala.

Villagomez, J. (2018, May 1). Seeking asylum in the U.S. under Trump. Retrieved from https://www.pbs.org/newshour/politics/seeking-asylum-in-the-u-s-under-trump

Yates-Doerr, E. (2018, October 25). Why Are So Many Guatemalans Migrating to the U.S.? Retrieved from https://www.sapiens.org/culture/guatemala-migrants-united-states/ 